\title{
Use of Renewable Energy Technologies in Buildings
}

\author{
John Vourdoubas* \\ Mediterranean Agronomic Institute of Chania, Greece
}

Submission: October 10, 2018; Published: October 23, 2018

*Corresponding author: John Vourdoubas, Mediterranean Agronomic Institute of Chania, Greece; Tel: 306933000000; Email: vourdoubas@maich.gr

\begin{abstract}
Global climate change has increased the interest and the efforts in using renewable energy sources instead of fossil fuels in all sectors of the economy. Use of benign energy sources in buildings is easier than in industry and in transport. Renewable energies like solar energy, solid biomass and low enthalpy geothermal energy, if available, are currently used in buildings for generation of heat, cooling and electricity covering part or all of their energy needs. Due to technological improvements various renewable energy technologies are currently reliable and cost effective. Their combined use could result in the creation of net zero energy buildings and net zero carbon emission buildings due to energy use.
\end{abstract}

Keywords: Buildings; Cooling; Electricity; Ground source heat pumps; Heat; Renewable energies; Solar energy; Solid biomass

\section{Introduction}

Various reports regarding the use of renewable energy technologies in buildings have been published and a lot of research has been implemented in this field. Currently, in regions with high availability, the use of renewable energies in buildings is a standard practice without any economic support due to their cost effectiveness. Vinubhai et al.[1] have reviewed solar water heating systems. They mentioned that solar water heating is one of the most effective energy technologies to convert solar energy into thermal energy and is considered to be a developed and commercialized technology. Many solar heaters do not require electricity to operate. They have an insulated hot water storage tank which provides hot water during periods of low solar irradiance. The authors stated that depending on the geographical area simple thermosiphonic solar thermal systems can cover the most of the hot water requirements in residential buildings.

Wenjie et al. [2] have reported on solar photovoltaic (solarPV) applications in buildings in China. The authors stated that solar-PVs in China are mainly installed in industrial buildings while their use in residential and commercial buildings is rather limited. They have also stated that the average efficiency of monocrystalline and poly-crystalline modulus is at $8-10 \%$ while the efficiency of amorphous cells is roughly at $6 \%$. Bobrova [3] has reported on building integrated wind turbines. She mentioned that efforts of architects are directed on integrating renewable energy technologies, including wind turbines, in buildings achieving harmonious results. International Energy Agency [4] has published a report concerning solar cooling. The report mentions that solar cooling is currently at a critical stage and it has reached at a level of early market deployment. Most planners, manufacturers and installers have limited experience with this technology. The report suggests the adoption of measures to support market development with the construction of largescale demonstration programs. Good et al. [5] have studied the use of solar energy with hybrid systems in buildings comparing solar thermal, solar-PV and hybrid solar thermal-PV systems for achieving a net zero energy building. The authors implementing computer simulations have concluded that high efficiency solarPV modulus was more attractive followed by the system with high performance solar thermal collectors and PV modulus.

Ferrante et al. [6] have reported on residential buildings with zero energy balance and zero on-site $\mathrm{CO}_{2}$ emissions in Mediterranean region. The authors stated that the creation of zero on-site $\mathrm{CO}_{2}$ emissions residential buildings in Mediterranean region is feasible. They indicated that it can be achieved combining energy saving techniques and passive tools with solar and wind energy micro-generation. Carlini et al. [7] have reported on economic assessment of biomass boiler plants used in Italian residential buildings. The authors stated that solid biomass is increasingly used in Italian houses with wood and pellet boilers for heating purposes and hot water supply. Assessing the economic feasibility of biomass heating in two Italian residential buildings the authors have reported positive net present values and payback periods varying between 9 and 14 years.

Ericsson et al. [8] have reported on the use of biomass in Swedish district heating systems. The authors stated that district heating satisfies about $60 \%$ of the heat demand in Swedish buildings while biomass alone accounts for about the half of the 


\section{Civil Engineering Research Journal}

heat supply. They mentioned that biomass expansion in district heating systems in Sweden was supported by governmental and municipal policies while the district heating sector was mainly relied on domestic wood fuels. Sarbu et al. [9] have reviewed ground source heat pumps (GSHPs) for heating and cooling buildings. The authors stated that GSHPs are increasingly used in residential and commercial buildings for heating and cooling purposes. They also mentioned that they have high coefficient of performance while they are more effective than traditional systems in heating and cooling buildings. Hafez et al. [10] have investigated the use of a solar parabolic dish Stirling engine system in Egypt. Studying a system with nominal capacity at $10 \mathrm{KW}$ the authors estimated the output of the Stirling engine at 9,707W where the maximum beam solar irradiance was $990 \mathrm{~W} / \mathrm{m} 2$.Vourdoubas [11] has reported on the creation of net zero carbon emissions residential buildings due to energy use in Crete, Greece. The author indicated that the combined use of solar thermal energy, solar-PV, solid biomass and GSHPs in a residential building could zero its net carbon emissions due to operating energy use. Renewable energy technologies used for energy generation in buildings are presented inTable 1.

Table 1: Renewable energy technologies used for energy generation in buildings.

\begin{tabular}{|c|c|c|c|}
\hline Renewable Energy & Renewable Energy technology & Generated Energy & Currently Used \\
\hline Solar energy & Solar thermal systems with flat plate collectors & Hot water & Yes, broadly \\
\hline Solar energy & Solar thermal cooling & Space cooling & Yes, occasionally \\
\hline Solar energy & Hybrid solar systems & Heat and electricity & No, there are only few commercial systems \\
\hline Solar energy & Solar-PV & Electricity & Yes \\
\hline Solid biomass & Solid biomass burning & Heat & Yes, broadly \\
\hline Heat of the ground & Ground source heat pumps & Heat & Yes, broadly \\
\hline Solid biomass & District heating using solid biomass & Electricity & $\begin{array}{c}\text { Few commercial systems mainly used in off-grid } \\
\text { buildings }\end{array}$ \\
\hline Wind energy & Wind turbines &
\end{tabular}

\section{Conclusion}

Technological innovations and improvements of various renewable energy technologies have reduced their cost allowing their use in buildings without any economic support. Currently they can be used for heating and cooling purposes as well as for power generation. However, the most of them are used for heat generation. Various renewable energy technologies including solar thermal energy for hot water production, solar-PV for power generation, solid biomass for heat generation and high efficiency heat pumps for heat and cooling production are currently mature, reliable, cost effective and they are broadly used in buildings. Some of them including hybrid solar systems, thermal driven solar cooling, small wind turbines and solar parabolic dishes with Stirling engines need further improvements in order to increase their reliability and cost effectiveness. Their use in buildings for heat and electricity generation results in many economic, social and environmental benefits contributing to the mitigation of the greenhouse effect and climate change.

\section{References}

1. Vinubhai TS, Vishal RJ, Thakkar K (2014) A review: Solar water heating systems. National conference on emerging Vista of technology in the 21st century. Vadodara, India.

2. Wenjie Z, Bin H, Nianping L, Shan L, Chunni Y (2015) Investigation of photovoltaic application in buildings in China. Energy Procedia 70: 673-682.
3. Bobrova D (2015) Building-Integrated wind turbines in the aspect of Architectural shaping. Procedia Engineering 117: 404-410.

4. International Energy Agency, Task 38 (2011) Solar air conditioning and refrigeration, Solar Cooling position paper, Freiburg, Germany, pp. $1-20$.

5. Good C, Andresen I, Hestnes AG (2015) Solar energy for net zero energy buildings - A comparison between solar thermal, PV and photovoltaicthermal (PV/T) systems. Solar Energy 122: 986-996.

6. Ferrante A, Cascella MT (2011) Zero energy balance and zero on-site CO2 emission housing development in Mediterranean climate. Energy and Buildings 43(8): 2002-2010.

7. Carlini M, Castellucci S, Cocchi S, Allegrini E, Li M (2013) Italian residential buildings: Economic assessment for biomass boilers plants. Mathematical Problems in Engineering 2013: 1-10.

8. Ericsson K, Werner S (2016) The introduction and expansion of biomass use in Swedish district heating systems. Biomass and Bioenergy 94: 57-65.

9. Sarbu I, Sebarchievici C (2014) General review of ground source heat pump systems for heating and cooling buildings. Energy and Buildings 70: $441-454$.

10. Hafez AZ, Soliman A, El-Metwall KA, Ismail IM (2016) Solar parabolic disc Stirling engine system design, simulation and thermal analysis. Energy Conversion and Management 126: 60-75.

11.Vourdoubas J (2016) Creation of zero $\mathrm{CO}_{2}$ emission residential building due to energy use: A case study in Crete, Greece. Journal of Civil Engineering and Architecture Research 3(2): 1251-1259. 

(C) (1) l $\begin{aligned} & \text { This work is licensed under Creative } \\ & \text { Commons Attribution 4.0 License } \\ & \text { DOI: } 10.19080 / C E R J .2018 .06 .555693\end{aligned}$

\section{Your next submission with Juniper Publishers} will reach you the below assets

- Quality Editorial service

- Swift Peer Review

- Reprints availability

- E-prints Service

- Manuscript Podcast for convenient understanding

- Global attainment for your research

- Manuscript accessibility in different formats

( Pdf, E-pub, Full Text, Audio)

- Unceasing customer service

Track the below URL for one-step submission https://juniperpublishers.com/online-submission.php 